Article

\title{
Anti-Cancer Activity of Catechin against A549 Lung Carcinoma Cells by Induction of Cyclin Kinase Inhibitor p21 and Suppression of Cyclin E1 and P-AKT
}

\author{
Haiyan Sun ${ }^{1}$, Meichen Yin ${ }^{1}$, Danqing Hao ${ }^{1}$ and Yixiao Shen ${ }^{2, *(D)}$ \\ 1 Key Laboratory of Life Resources of Shaanxi Province, College of Biological Science and Engineering \\ Shaanxi, University of Technology, Hanzhong 723000, China; diyson2008@163.com (H.S.); \\ yuanmengsyyy@163.com (M.Y.); haodanqing@126.com (D.H.) \\ 2 College of Food Science, Shenyang Agricultural University, Shenyang 110161, China \\ * Correspondence: shenyixiao87@126.com
}

Received: 5 February 2020; Accepted: 11 March 2020; Published: 19 March 2020

\begin{abstract}
Catechin is one of the major polyphenols in teas, beans, and berry fruits. A number of studies have confirmed that catechins extract possesses health benefits in the prevention of various chronic diseases. In this study, the anti-cancer activity and mechanism of catechin against non-small cell lung cancer A549 cells were investigated. The inhibitory rate of catechin on the proliferation of A549 cells reached $19.76 \%$ at a concentration of $600 \mu \mathrm{mol} \cdot \mathrm{L}^{-1}$ with $24 \mathrm{~h}$ incubation. The results demonstrated that catechin inhibits A549 cells by increasing the expressions of p21 and p27 in the cancer cells. Furthermore, the catechin treatment inhibited the expressions of cyclin E1 and phosphorylation of protein kinase (P-AKT) in a dose-dependent manner, which also contributed to the inhibition of cancer cell proliferation. Therefore, the results of this study indicated that catechin can effectively inhibit the proliferation of A549 cells through regulating its cell cycle arrest or indirectly via the p21 signaling pathway. It would provide important information for developing catechin and catechin-rich functional food or co-therapy for antitumor purposes.
\end{abstract}

Keywords: catechin; non-small cell lung cancer; cyclinE; AKT; cyclin kinase inhibitor

\section{Introduction}

Lung cancer is one of the prevalent cancers in the world and non-small cell lung carcinoma represents $80 \%$ of lung cancers [1]. Current standard therapies only contribute to $15 \%$ of the survival rate within overall 5-year survival, because this cancer is a systemic disease [2]. Cell cycle in cancer-genesis is one of the key pathways to control cancer cell progression [3]. It is regulated by the coordinated activation of a cyclin-dependent kinase (CDK)/cyclin complex. Especially, Cyclin E binds CDK2 to activate the cyclinE/CDK2 complex at early phase (G1/S) of the cell cycle, which can be controlled by the phosphorylation of tumor suppressor proteins [4]. Both cyclin kinase inhibitors p21 and p27 are able to regulate CDK by binding to CDK and proliferating cell nuclear antigen (PCNA). Then, p21 and p27 lead to cancer-cell-cycle arrest and the blockade of DNA synthesis to inhibit cancer cell proliferation [5]. On the other hand, AKT, known as protein kinase $\mathrm{B}$, also plays a key role in cancer cell proliferation, survival and metabolism [6]. The hyperactivation of AKT has been found to contribute to the misregulation of cell cycle progression in several types of human cancers [7]. The phosphorylated AKT (P-AKT) has been reported to promote cancer progression and cancer drug resistance [8]. Thus, the improvement of p27 and p21 expression and deduction of P-AKT could have potential prognostic and therapeutic implications in human cancers [9]. 
Catechins are a group of common polyphenols present in tea, red wine, cocoa and other leaf or fruit drinks [10]. A number of studies have confirmed that catechin extract possesses health benefits through the prevention of various chronic diseases. For example, catechin-rich tea extract has shown significant effects in animal models on anti-mutation, immune regulation, and cardiovascular system health, especially in delaying tumor onset [11]. The mechanisms of the health benefits have been reported to be associated with the great antioxidant activity of catechins [12]. Basically, catechins are polyphenol-based secondary metabolites with a structure of two linked phenols benzopyran derivatives [13]. Different from most other catechins, which naturally contain one or more glucoside groups, catechin is the most basic catechin compound without glycosylation, resulting in higher bioavailability and absorption efficiency in the body [14]. Epigallocatechin-3-gallate, a major compound in the catechins group, or natural catechins extract, was usually used to examine the anti-cancer activity of catechins. For example, epigallocatechin-3-gallate in green tea was selected to investigate the expression of the cancer cell cycle regulatory gene [15]. Plum catechins extract was applied to induce apoptosis in human hepatoma HepG2 cells [16]. However, the mechanism of the anti-cancer activity of the most basic catechin has not been studied. In order to understand the action site inhibiting cancer cell proliferation, pure catechin was used in this study. The inhibitory effects on A549 cancer cells' proliferation, and the p21/ p27 expression of A549 cells were determined. The levels of Cyclin E 1 and P-AKT in the cancer cell after being treated by catechin were also analyzed. Therefore, this study could reveal the mechanism of the anti-cancer activity of the basic catechin compound without interference from other catechins or co-existing extracted compounds. The results would be helpful in understanding the potential and the mechanisms of catechin compounds from natural beverages and foods on cancer prevention.

\section{Materials and Methods}

\subsection{Materials}

The non-small cell lung cancer A549 cell line was originally from American Type Culture Collection (ATCC, Manassas, VA, USA). Catechin standard and real-time quantitative PCR primers were purchased from the Suolaibao Technology and Dingsheng Biological Co., Ltd. (Beijing, China), respectively. SYBR for qPCR was purchased from Takara Bio (Tokyo, Japan) and RNA reverse transcription kit was purchased from Dalian Bao Bioengineering Co., Ltd. (Beijing, China). RNA extraction kit was from Bioflux Co., Ltd. (Beijing, China). Yeast extract "OXOID" and RIPA lysis solution were from Thermo Scientific Co. (Waltham, MA USA). Immunoblotting chemiluminescence reagent, SDS, and CCK-8 (cell count kit -8) were purchased from BioTech Co. (Beijing, China).

\subsection{Determination of $A 549$ Cell Proliferation}

The A549 cells in Dulbecco's modified Eagle's medium (DMEM) containing 10\% fetal bovine serum (FBS) were seeded in a 96-well plate with a density of 5500 cells in each well. The cells were incubated at $37^{\circ} \mathrm{C}$ under $5 \% \mathrm{CO}_{2}$ for $24 \mathrm{~h}$. The cells were synchronized in $\mathrm{G} 1$ phase and the original medium in each well was discarded. Then, $1 \mathrm{~mL}$ of fresh DMEM medium containing 200, 400, or 600 $\mu \mathrm{mol}$ of catechin per liter was added. Fresh DMEM medium without catechin was used as a control group. The cells were then incubated at the same condition as described above. After $24 \mathrm{~h}$ incubation, the cell proliferation was measured. After each well was washed by phosphate-buffered saline (PBS) twice, $100 \mu \mathrm{L}$ of the fresh medium and $10 \mu \mathrm{L}$ of CCK- 8 reagent was added. After $1 \mathrm{~h}$ incubation, the absorbance of each well was measured at $450 \mathrm{~nm}$. The anti-proliferation rate of catechin was calculated by dividing the absorbance difference of control and treatment by the absorbance of control, then expressed in percentage.

\subsection{Determination of Cyclin Kinase Inhibitors $p 21$ and $p 27$ Expression}

Based on the dose-dependent anti-proliferation activity, A549 cells treated by the DMEM medium with low $\left(200 \mu \mathrm{mol} \cdot \mathrm{L}^{-1}\right)$ and high $\left(600 \mu \mathrm{mol} \cdot \mathrm{L}^{-1}\right)$ concentrations of catechin were selected to evaluate 
the cyclin kinase inhibitors p21 and p27 expression levels. The cells treated by the medium without catechin were used as control. The total RNA of cells in each group was extracted using Trizol reagent. Then, cDNA was produced based on the RNA reverse transcription kit protocol and applied as a template for PCR analysis. qPCR was performed by based on the instruction of the SYBR kit (Takara Bio, Tokyo, Japan). The primer sequences for p21, p27, and GAPDH (Human glyceraldehydes-3-phosphate dehydrogenase) control were shown in Table 1 . The qPCR reaction mixture consisted of $5 \mu \mathrm{L}$ of SYBR Premix, $0.8 \mu \mathrm{L}$ of forward primer, $0.8 \mu \mathrm{L}$ of reverse primers, $1.0 \mu \mathrm{L}$ of template DNA, and $2.4 \mu \mathrm{L}$ of nuclease-free water. The program of qPCR was set at an initial denaturation at $95^{\circ} \mathrm{C}$ for $5 \mathrm{~min}, 40$ cycles of $95^{\circ} \mathrm{C}$ for $30 \mathrm{~s}, 60^{\circ} \mathrm{C}$ for $30 \mathrm{~s}$, and $72{ }^{\circ} \mathrm{C}$ for $30 \mathrm{~s}$, and final extension at $72{ }^{\circ} \mathrm{C}$ for $10 \mathrm{~min}$. Then, the reaction was maintained at $12{ }^{\circ} \mathrm{C}$. The qPCR analysis for each gene was repeated in triplicates. The expression values for each target gene were normalized to GAPDH by the relative gene expression method.

Table 1. Primer sequences of qPCR analysis.

\begin{tabular}{cc}
\hline Gene & Sequence $\left(\mathbf{5}^{\prime}\right.$ to $\mathbf{3}^{\prime}$ ) \\
\hline \multirow{2}{*}{ p21 } & F:ACCGAGACACCACTGGAGGG \\
& R: CCTGCCTCCTCCCAACTCATC \\
p27 & F:CCTCCTCCAAGACAAACAGCG \\
& R:GGGCATTCAGAGCGGGATT \\
GAPDH & F:GCACCGTCAAGGCTGAGAAC \\
& R:TGGTGAAGACGCCAGTGGA \\
\hline
\end{tabular}

\subsection{Determination of Cyclin E 1 and P-AKT Expression}

The control and treated cells were rinsed with PBS after $24 \mathrm{~h}$ of incubation. Then, the cells were lysed using radio-immunoprecipitation assay (RIPA) lysis solution. The lysed protein was collected and placed in an ice bath for $30 \mathrm{~min}$. Then, it was mixed with a protein loading buffer and heated to boiling. After the mixture cooled down, total protein was extracted by centrifugation at $10,000 \times \mathrm{g}$ for $5 \mathrm{~min}$. The extracted protein was loaded onto the sodium dodecyl sulfate-polyacrylamide gel electrophoresis (SDS-PAGE) gel (12\% separation gel and 5\% concentrated gel) and then transferred onto a micro porouspoly vinylidene difluoride (PVDF) membrane. The transferred membrane was placed into an electrophoresis tank with buffer to carry out electrophoresis for $2 \mathrm{~h}$ in ice bath. The membrane was blocked with Tris-buffered saline with Tween-20 (TBST) for more than $5 \mathrm{~h}$. After the TBST buffer (Tris-buffered saline, $0.1 \%$ Tween 20) was discarded, the membrane was incubated with specific primary antibodies in TBST at room temperature for $2 \mathrm{~h}$ and then washed with TBST three times. The membranes were then incubated with secondary antibodies for $1 \mathrm{~h}$ at $26^{\circ} \mathrm{C}$ and washed with TBST. The protein bands in the membrane were detected with an enhanced chemiluminescence (ECL) detection system. $\beta$-Actin was used for normalization of the Western blot analysis to obtain the expression values of cyclin E 1, AKT, and P-AKT.

\subsection{Statistical Anlysis}

All data were expressed as mean \pm standard deviation. Students' $t$-test was performed using SPSS 17.0 statistical software (IBM Company, New York, NY, USA) to compare the control and treated groups as well as between treated groups. A significant difference was reported when $p<0.05$.

\section{Results and Discussions}

\subsection{The Anti-Proliferation Effect of Catechin on A549 Cancer Cells}

After $24 \mathrm{~h}$ incubation, the anti-proliferation rates of catechin against A549 cancer cell were listed in Table 2. The images of the cells in control and treatment groups were shown in Figure 1. The anti-proliferation rate of catechin was in a dose-dependent manner. As the catechin concentration 
increased from 200 to $600 \mu \mathrm{mol} \cdot \mathrm{L}^{-1}$, the anti-proliferation rate increased from $0.73 \pm 0.25 \%$ to $19.76 \pm 0.72 \%$ Table 2 . It was comparable with epigallocatechin-3-gallate that $5-10 \%$ of A549 cells were inhibited as epigallocatechin-3-gallate concentration reached $100 \mu \mathrm{mol} \cdot \mathrm{L}^{-1}$ in the study of Sakamoto et al. (2013) [17]. Another catechin belonging to the same flavonoid group and its derivative compounds have been reported as exhibiting an effective inhibitory performance on cancer cell growth [18]. For example, epigallocatechingallate (EGCG), showed an anti-proliferation effect on A549 cells through the inhibition of the pro-apoptotic gene [18]. Flavonoids also had an affinity towards the adenosine triphosphate (ATP)-binding site of the Cdk4, which was a potential inhibitor targeting the retinoblastoma protein for the treatment of retinoblastoma [19]. Furthermore, the antioxidant activities of flavonoids were significantly correlated to anti-proliferative activities on cancer cell growth [20].

Table 2. Inhibition rates of catechin against A549 cells proliferation.

\begin{tabular}{cc}
\hline Concentration $\left(\boldsymbol{\mu m o l} \cdot \mathbf{L}^{-\mathbf{1}}\right)$ & Inhibition Rate $\mathbf{( \% )}$ \\
\hline 200 & $0.73 \pm 0.25^{*}$ \\
400 & $2.96 \pm 1.71 *$ \\
600 & $19.76 \pm 0.72 *$ \\
\hline
\end{tabular}

* significant difference between two data at $p<0.05$.
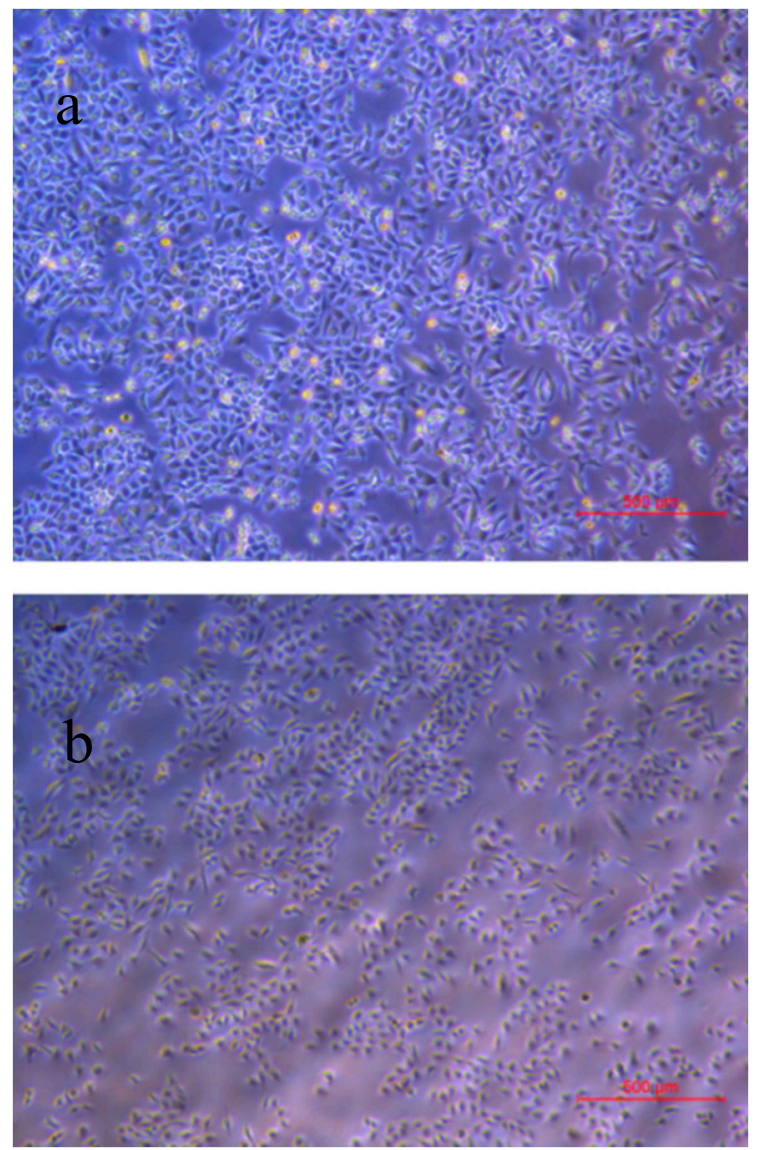

Figure 1. Images of the A549 cells in control (a) and catechin $(600 \mu \mathrm{moL})$ treatment (b) groups after $24 \mathrm{~h}$ of incubation.

\subsection{Effect of Catechin on Cyclin Kinase Inhibitors $p 21$ and $p 27$ Expressions in A549 Cancer Cells}

Cell cycle progression is driven by cyclins which are associated with CDK [9]. As an inhibitor of cyclin dependent kinase, p27 was involved in the regulation of the cancer cell cycle [21]. 
Increasing oncology researches focused on p27 as the target therapy in breast cancer treatment [22]. Similar to p27, p21 has been reported to increase tumor cell susceptibility. A previous study showed that the expression of p21 resulted in the accumulation of cells in G0/G1, altering cell morphology and differentiation [23]. In addition, p21 has been reported to mediate the p53-induced G1 cell cycle arrest resulting from DNA damage [24]. Thus, the effect of catechin on cyclin kinase inhibitors p21 and p27's expression in A549 cancer cells were both evaluated in this study. Because anti-proliferation results showed the dose dependency, only the lowest and highest concentrations of catechin (200 and $600 \mu \mathrm{mol} \cdot \mathrm{L}^{-1}$ ) treatments were selected to evaluate the expression of cyclin kinase inhibitors p21 and p27.

As shown in Figure 2, the expression of p21 significantly increased in the 200 and $600 \mu \mathrm{mol} \cdot \mathrm{L}^{-1}$ treatment groups by approximately 1.3 and 1.2 times, respectively $(\mathrm{p}<0.05)$ compared to the control group. However, there was no significant difference between the two catechin treatment groups, indicating that the improvement of p21 might have reached a plateau when catechin concentration was at $200 \mu \mathrm{mol} \cdot \mathrm{L}^{-1}$. No significant incensement of p27 expression was observed in catechin treatments and control group, Figure 2. Thus, p21 might have a more sensitive response to catechin than p27 in A549 cells. A number of bioactive compounds have been evidenced to inhibit cancer cells' proliferation though enhancing the expression of p21 or p27, which further reduced the activity of cyclin E. For instance, p21 significantly increased in EGCG-treated A549 cells [25]. In addition, caffeic acid phenyl ester has been shown to arrest castration-resistant prostate cancer cells by upregulating p21 and $\mathrm{p} 27$ proteins [26].

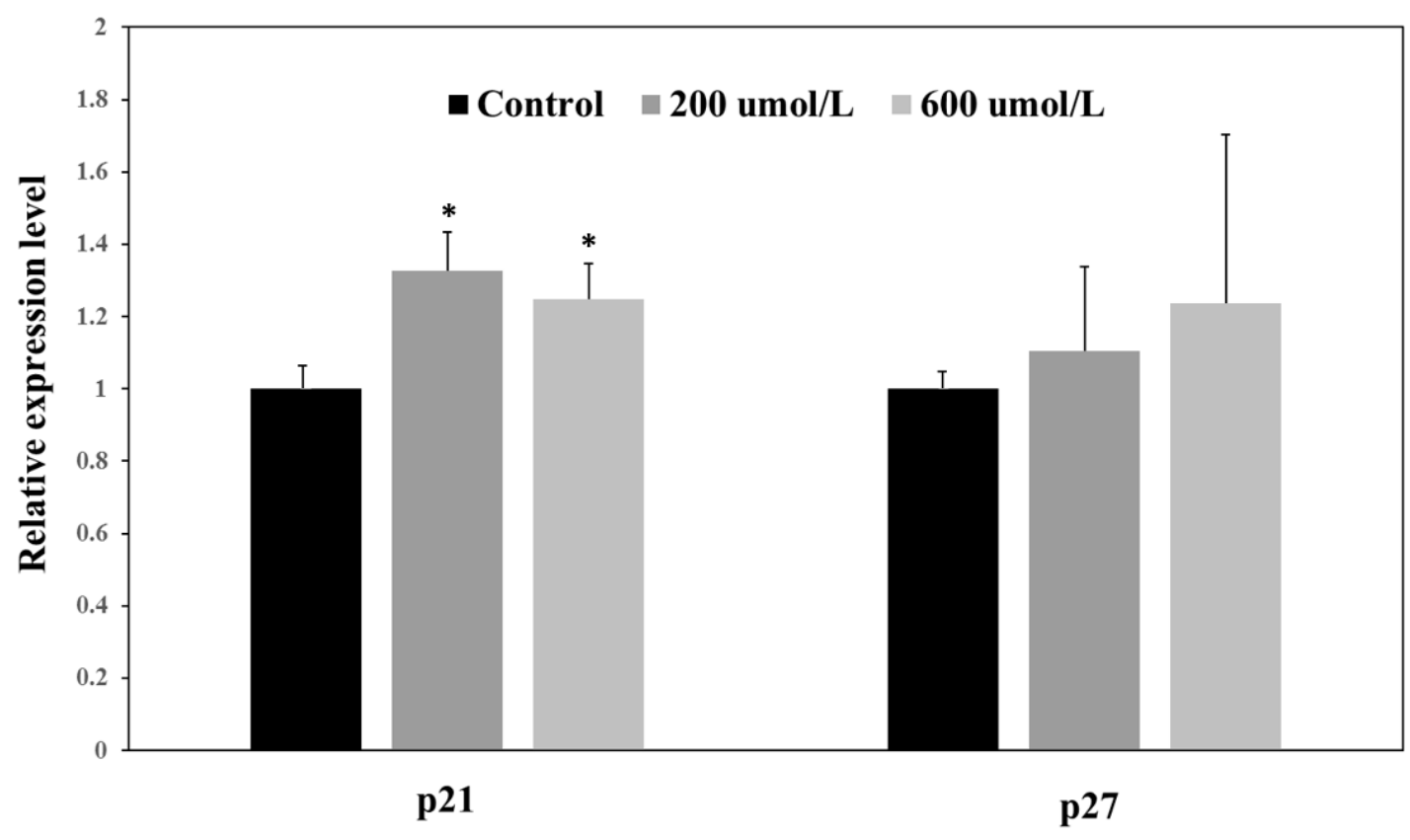

Figure 2. Relative expression levels of cyclin kinase inhibitor p21 and p27 in control, 200 and $600 \mu \mathrm{mol} \cdot \mathrm{L}^{-1}$ treatment groups. * Significant difference between each treatment and control in each cyclin kinase inhibitor at $p<0.05$.

\subsection{Effect of Catechin on Cyclin E1 and P-AKT Expressions in A549 Cancer Cells}

Cyclin E1 is a positive regulator in the cell cycle and the overexpression of cyclin E1 in tumors would contribute to tumorigenesis [27]. Cyclin E1 is important in cancer tumor growth and proliferation, particularly in breast cancer [28]. Phosphorylated RAC- $\alpha$ serine/threonine-protein kinase (P-AKT) is the activated form of AKT. It plays a critical role in the development, progression and metastatic spread of breast cancer [29]. Thus, cyclin E1 and P-AKT were used as the primary indicators to evaluate the efficiency of catechin in inhibiting A549 cell proliferation. As shown in Figure 3, the levels of P-AKT 
significantly decreased in the $200 \mu \mathrm{mol} \cdot \mathrm{L}^{-1}$ treatment group. Catechin inhibited cyclin E1 expression in a dose-dependent manner. When the catechin concentration was $200 \mu \mathrm{mol} \cdot \mathrm{L}^{-1}$, the E1 expression was approximately $50 \%$ lower than the control group, and it was $70 \%$ lower than control group when the caetchin concentration was the $600 \mu \mathrm{mol} \cdot \mathrm{L}^{-1}$ treatment, Figure 3. This was in accordance with the trend of the catechin-treated A549 cell, where the A549 proliferation was significantly inhibited in a dose-dependent manner, Table 2. Thus, the inhibition of P-AKT expression led to the downregulation of cyclin E1, and subsequently inhibited cancer cell growth. This was in agreement with the theory that the tea polyphenols, EGCG, reduced the viability of cancer cell by inhibiting signaling proteins like AKT directly [15]. Red wine was reported to cause a remarkable inhibition of basal AKT phosphorylation in A549 cells [18]. Catechin is one of the major phenolics in red wine, thus it would partially contribute to the inhibition of efficiency for inhibiting AKT expression and phosphorylation in red wine [18]. Therefore, catechin was involved in the regulation of A549 cancer cell cycle arrest through directly inhibiting cyclin E1 expression, or indirectly via p21 signaling pathway, in this study.
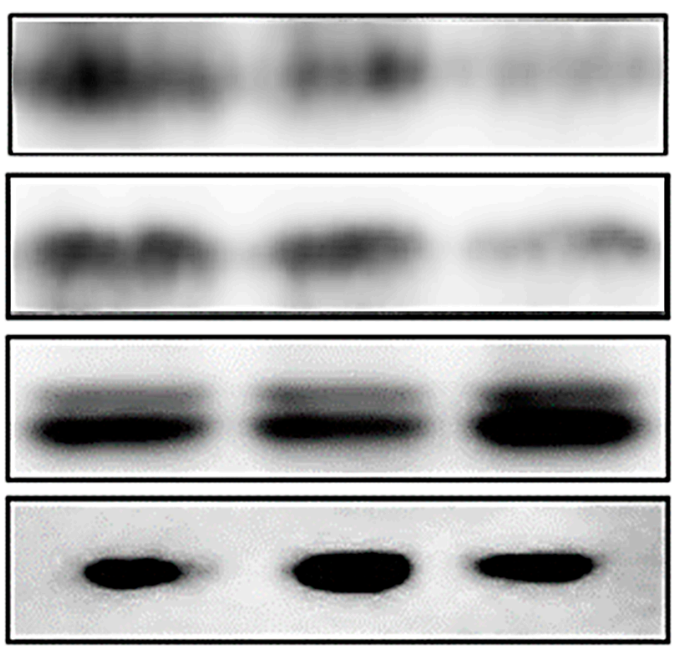

\section{CyclinE}

\section{P-AKT}

\section{AKT \\ $\beta$-actin}

\section{Control $200 \mu \mathrm{mol} 600 \mu \mathrm{mol}$}

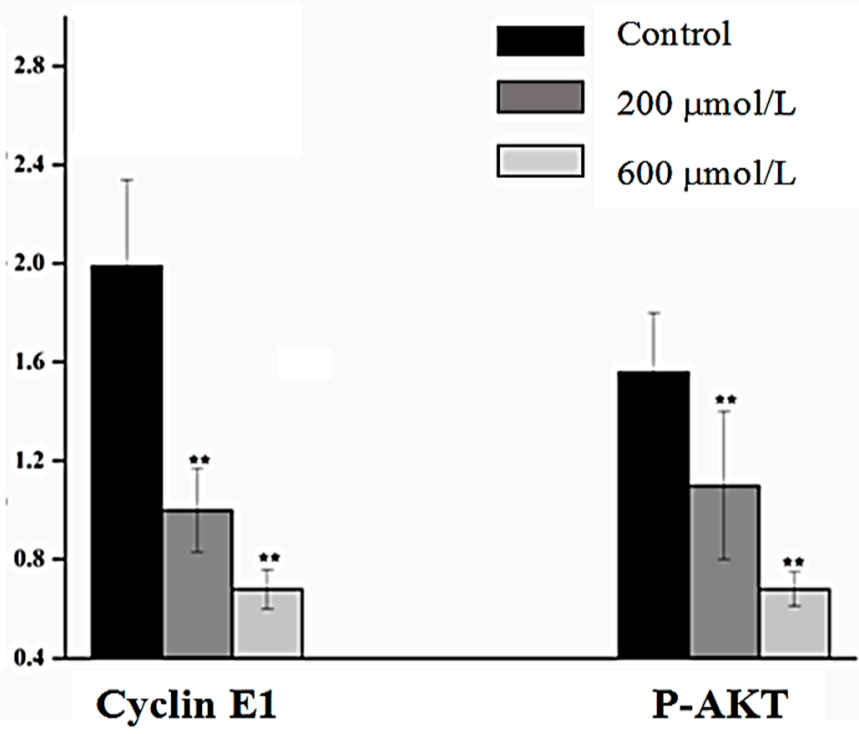

Figure 3. Images of Western blot analysis (top) and relative expression levels (bottom) of cyclin E1/ $\beta$-actin and P-AKT/AKT in control, 200 and $600 \mu \mathrm{mol} \cdot \mathrm{L}^{-1}$ treatment groups. 


\section{Conclusions}

In conclusion, the results of the present study demonstrate that catechin had an inhibitory effect on A549 cancer cell proliferation. The cancer cell growth appeared to be mediated through the inhibition of the metabolism enzyme cyclin E1, upregulation of p21, and downregulation of AKT and P-AKT protein expression. These observations indicate that catechin and catechin-rich foods such as wine may be useful as an antitumor agent to enhance the efficacy of cancer therapy.

Author Contributions: Methodology, M.Y.; formal analysis, D.H.; writing-original draft preparation, H.S.; writing-review and editing, Y.S. All authors have read and agreed to the published version of the manuscript.

Funding: This research was funded by Open Project of Shanxi Province Key Laboratory of Resource Biology, grant number SLGPT2019KF03-05; Post Subsidy Project of Shanxi Province Key Laboratory of Resource Biology, grant number 2018SZS-27-04.

Conflicts of Interest: The authors declare no conflict of interest. The funders had no role in the design of the study; in the collection, analyses, or interpretation of data; in the writing of the manuscript, or in the decision to publish the results.

\section{References}

1. Bettuzzi, S.; Brausi, M.; Rizzi, F.; Castagnetti, G.; Peracchia, G.; Corti, A. Chemoprevention of human prostate cancer by oral administration of green tea catechins in volunteers with high-grade prostate intraepithelial neoplasia: A preliminary report from a one-year proof-of-principle study. Cancer Res. 2006, 66, 1234-1240. [CrossRef] [PubMed]

2. Zhu, J.; Chen, M.; Chen, N.; Ma, A.; Zhu, C.; Zhao, R.; Jiang, M.; Zhou, J.; Ye, L.; Fu, H.; et al. Glycyrrhetinic acid induces G1phase cell cycle arrest in human nonsmallcell lung cancer cells through endoplasmic reticulum stress pathway. Int. J. Oncol. 2015, 46, 981-988. [CrossRef] [PubMed]

3. Tian, Y.E.; Wan, H.A.N.; Tan, G. Cell cycle-related kinase in carcinogenesis. Oncol. Lett. 2012, 4, 601-606. [CrossRef]

4. Brambilla, E.; Gazdar, A. Pathogenesis of lung cancer signalling pathways: Roadmap for therapies. Eur. Respir. J. 2009, 33, 1485-1497. [CrossRef]

5. Xia, X.; Ma, Q.; Li, X.; Ji, T.; Chen, P.; Xu, H.; Li, K.; Fang, Y.; Weng, D.; Weng, Y.; et al. Cytoplasmic p21 is a potential predictor for cisplatin sensitivity in ovarian cancer. BMC Cancer 2011, 11, 399. [CrossRef]

6. Ardito, F.; Giuliani, M.; Perrone, D.; Troiano, G.; Muzio, L.L. The crucial role of protein phosphorylation in cell signaling and its use as targeted therapy (Review). Int. J. Mol. Med. 2017, 40, 271-280. [CrossRef]

7. Xu, C.X.; Jin, H.; Shin, J.Y.; Kim, J.E.; Cho, M.H. Roles of protein kinase B/Akt in lung cancer. Front Biosc. 2010, 2, 1472-1484.

8. Liu, W.; Zhang, L.; Shi, J.; Liu, Y.; Zhou, L.; Hou, K.; Qu, X.; Teng, Y. Clinical significance of pAkt and pErk1/2 expression in early-stage breast cancer patients treated with anthracycline-based adjuvant chemotherapy. Oncol. Lett. 2015, 9, 1707-1714. [CrossRef]

9. Wander, S.A.; Zhao, D.; Slingerland, J.M. A Barometer of signaling deregulation and potential predictor of response to targeted therapies. Clin. Cancer Res. 2011, 17, 12-18. [CrossRef]

10. $\mathrm{Xu}, \mathrm{Z}$. Important antioxidant phytochemicals in agricultural food products. In Analysis of Antioxidant-Rich Phytochemicals; Xu, Z., Howard, L.R., Eds.; Wiley-Blackwell Publisher: Oxford, UK, 2012; pp. 1-24.

11. Singh, B.N.; Shankar, S.; Srivastava, R.K. Green tea catechin, epigallocatechin-3-gallate (EGCG): Mechanisms, perspectives and clinical applications. Biochem. Pharmacol. 2011, 82, 1807-1821. [CrossRef]

12. Bell, J.R.C.; Donovan, J.L.; Wong, R.; Waterhouse, A.L.; German, J.B.; Walzem, R.L.; Kasim-Karakas, S.E. (+)-Catechin in human plasma after ingestion of a single serving of reconstituted red wine. Am. J. Clin. Nutr. 2000, 71, 103-108. [CrossRef]

13. Panche, A.N.; Diwan, A.D.; Chandra, S.R. Flavonoids: An overview. J. Nutr. Sci. 2016, 5, e47. [CrossRef]

14. Batra, P.; Sharma, A.K. Anti-cancer potential of flavonoids: Recent trends and future perspectives. Biotech. 2013, 3, 439-459. [CrossRef]

15. Milligan, S.A.; Burke, P.; Coleman, D.T.; Bigelow, R.L.; Steffan, J.J.; Carroll, J.L.; Williams, B.J.; Cardelli, J.A. The green tea polyphenol EGCG potentiates the antiproliferative activity of c-Met and epidermal growth factor receptor inhibitors in non-small cell lung cancer cells. Clin. Cancer Res. 2009, 15, 4885-4894. [CrossRef] 
16. Costa, M.I.; Boldrini, J.L. Chemotherapeutic treatments: A study of the interplay among drug resistance, toxicity and recuperation from side effects. Bull. Math. Biol. 1997, 59, 205-232. [CrossRef]

17. Sakamoto, Y.; Terashita, N.; Muraguchi, T.; Fukusato, T.; Kubota, S. Effects of epigallocatechin-3-gallate (EGCG) on A549 lung cancer tumor growth and angiogenesis. Biosci. Biotechnol. Biochem. 2013, 77, 1799-1803. [CrossRef]

18. Barron, C.C.; Moore, J.; Tsakiridis, T.; Pickering, G.; Tsiani, E. Inhibition of human lung cancer cell proliferation and survival by wine. Cancer Cell Int. 2014, 14, 6. [CrossRef]

19. Han, Y.; Chen, R.; Zhao, F. Docking analysis of some flavanols as Cdk-4 inhibitor as a possible option to treat retinoblastoma. Biomed. Res. 2017, 28, 1453-1457.

20. Wang, S.Y.; Lewers, K.S.; Bowman, L.; Ding, M. Antioxidant activities and anticancer cell proliferation properties of wild strawberries. J. Am. Soc. Hortic. Sci. 2007, 132, 647-658. [CrossRef]

21. Peyressatre, M.; Prevel, C.; Pellerano, M.; Morris, M.C. Targeting cyclin-dependent kinases in human cancers: From small molecules to peptide inhibitors. Cancers 2015, 7, 179-237. [CrossRef]

22. Schlotter, C.M.; Vogt, U.; Allgayer, H.; Brandt, B. Molecular targeted therapies for breast cancer treatment. Breast Cancer Res. 2008, 10, 211. [CrossRef] [PubMed]

23. Yang, Z.Y.; Perkins, N.D.; Ohno, T.; Nabel, E.G.; Nabel, G.J. The p21 cyclin-dependent kinase inhibitor suppresses tumorigenicityin vivo. Nat. Med. 1995, 1, 1052-1056. [CrossRef] [PubMed]

24. Koljonen, V.; Tukiainen, E.; Haglund, C.; Bohling, T. Cell cycle control by p21, p27 and p53 in Merkel cell carcinoma. Anticancer Res. 2006, 26, 2209-2212.

25. Cromie, M.M.; Gao, W. Epigallocatechin-3-gallate enhances the therapeutic effects of leptomycin B on human lung cancer a549 cells. Oxid. Med. Cell Longev. 2015, 2015, 217304. [CrossRef]

26. Anantharaju, P.G.; Gowda, P.C.; Vimalambike, M.G.; Madhunapantula, S.V. An overview on the role of dietary phenolics for the treatment of cancers. Nutr. J. 2016, 15, 99. [CrossRef]

27. Luo, Q.; Li, X.; Li, J.; Kong, X.; Zhang, J.; Chen, L.; Huang, Y.; Fang, L. MiR-15a is underexpressed and inhibits the cell cycle by targeting CCNE1 in breast cancer. Int. J. Oncol. 2013, 43, 1212-1218. [CrossRef]

28. Nakayama, N.; Nakayama, K.; Shamima, Y.; Ishikawa, M.; Katagiri, A.; Iida, K.; Miyazaki, K. Gene amplification CCNE1 is related to poor survival and potential therapeutic target in ovarian cancer. Cancer 2010, 116, 2621-2634.

29. Zhou, L.; Wang, M.; Guo, C.; Zhu, Y.; Yu, H.; Zhang, L.; Yu, P. Expression of pAkt is associated with a poor prognosis in Chinese women with invasive ductal breast cancer. Oncol. Lett. 2018, 15, 4859-4866. [CrossRef] 